\title{
The image of absence and the politics of naming in Shona war fiction
}

\begin{tabular}{|c|c|}
\hline \multicolumn{2}{|c|}{$\begin{array}{l}\text { Authors: } \\
\text { Willie L. Chigidi }{ }^{1,2} \\
\text { Davie E. Mutasa }{ }^{2}\end{array}$} \\
\hline \multicolumn{2}{|c|}{$\begin{array}{l}\text { Affiliations: } \\
{ }^{1} \text { Department of African } \\
\text { Languages, Midlands State } \\
\text { University, Zimbabwe }\end{array}$} \\
\hline \multicolumn{2}{|c|}{$\begin{array}{l}{ }^{2} \text { Department of African } \\
\text { Languages, University of } \\
\text { South Africa, South Africa }\end{array}$} \\
\hline \multicolumn{2}{|c|}{$\begin{array}{l}\text { Correspondence to: } \\
\text { Davie Mutasa }\end{array}$} \\
\hline \multicolumn{2}{|c|}{$\begin{array}{l}\text { Email: } \\
\text { mutasde@unisa.ac.za }\end{array}$} \\
\hline \multicolumn{2}{|c|}{$\begin{array}{l}\text { Postal address: } \\
\text { PO Box 392, University } \\
\text { of South Africa 003, } \\
\text { South Africa }\end{array}$} \\
\hline \multicolumn{2}{|c|}{$\begin{array}{l}\text { Dates: } \\
\text { Received: } 10 \text { Aug. } 2011 \\
\text { Accepted: } 17 \text { Jan. } 2013 \\
\text { Published: } 13 \text { May } 2013\end{array}$} \\
\hline \multicolumn{2}{|c|}{$\begin{array}{l}\text { How to cite this article: } \\
\text { Chigidi, W.L. \& Mutasa, D.E., } \\
2013 \text {, 'The image of absence } \\
\text { and the politics of naming in } \\
\text { Shona war fiction', Literator } \\
\text { 34(1), Art. \#419, } 10 \text { pages. } \\
\text { http://dx.doi.org/10.4102/ } \\
\text { lit.v34i1.419 }\end{array}$} \\
\hline \multicolumn{2}{|c|}{$\begin{array}{l}\text { Copyright: } \\
\text { (C) 2013. The Authors. } \\
\text { Licensee: AOSIS } \\
\text { OpenJournals. This work } \\
\text { is licensed under the } \\
\text { Creative Commons } \\
\text { Attribution License. }\end{array}$} \\
\hline \multicolumn{2}{|l|}{ Read online: } \\
\hline 口ifidn & $\begin{array}{l}\text { Scan this } Q R \\
\text { code with your } \\
\text { smart phone or } \\
\text { mobile device } \\
\text { to read online. }\end{array}$ \\
\hline
\end{tabular}

During Zimbabwe's liberation war thousands of young people crossed into neighbouring countries to take up arms to fight and end colonialism. There is sufficient evidence that many of these young people were women. Political rhetoric also maintains that women fought alongside their male counterparts. However, in the Shona literature that depicts Zimbabwe's guerrilla war there is a glaring absence of female characters who play the roles of guerrilla fighters. This article is an attempt to discuss this absence and to explain why there are very few guerrilla girls in Shona war fiction. The article argues that female guerrillas are not given much space in Shona war novels because the writers of these novels continue the oral folktale tradition in which women are rarely made heroines. It is further argued that in the actual guerrilla war of the 1970s female guerrillas were rarely seen fighting at the war front, that the pioneer guerrillas were men and that the masculine discourse about the war excluded women. Moreover, only men have written Shona war novels.

Die beeld van afwesigheid en die politiek van naamgewing in Shona-oorlogsfiksie. Tydens Zimbabwe se bevrydingsoorlog het duisende jong mense die grense van buurlande oorgesteek om wapens op te neem teen kolonialisme. Daar bestaan voldoende getuienis dat baie van hierdie jong mense vroulik was. Politieke retoriek het dit dan ook duidelik gemaak dat vroue saam met hul manlike eweknieë geveg het. In die Shona-literatuur wat Zimbabwe se guerrillaoorlog uitbeeld is daar egter ' $n$ skreiende afwesigheid van vroulike karakters wat die rolle van die guerrilla vegters uitbeeld. Hierdie artikel is 'n poging om hierdie beeld van afwesigheid te ontleed en te verduidelik waarom daar so min vroulike guerrillavegters in Shona-oorlogsfiksie voorkom. Die artikel argumenteer dat die skrywers van Shona-oorlogsromans dikwels die mondelinge volksverhaal waarin selde vroulike heldinne voorkom, voortgesit het. Daar word verder aangevoer dat in die werklike guerrilla-oorlog van die 1970's vroulike guerrillavegters selde gesien is waar hulle voor in die oorlog geveg het; dat die pionier guerrillavegters mans was; en dat die manlike diskoers oor die oorlog vroue uitgesluit het. Bowendien het slegs mans Shona-oorlogsromans geskryf.

\section{Introduction}

Zimbabwe's guerrilla war of the 1970s attracted a lot of attention from writers of fiction in the Shona language. Shona war fiction derives its material from this guerrilla war, a historical event in which almost the entire population alive at the time was involved in one way or another and an event on which so much was, has been, and continues to be said. The entire population referred to here includes women. There was a time during the earlier phases of the armed struggle in Zimbabwe when crossing the borders to go and join the liberation war was largely 'voluntary' and done by men. However, there came a time, especially in the middle phase of the war, that young people were abducted from schools without discrimination between sexes. These school children included young girls. In fact, in the 1970s there were deliberate efforts by guerrillas to recruit women as well. During the liberation war and after, politicians gave speeches in which they claimed that women fought and died alongside their male counterparts. On the surface of things therefore this was a guerrilla war that involved both male and female guerrillas. Yet a careful analysis of the fiction that talks about Zimbabwe's liberation war shows that female characters that play the role of guerrillas are conspicuous by their paucity or even absence. The purpose of this article is to discuss the possible reasons that explain why female guerrillas are very rare in fiction about a guerrilla war in which women are said to have played a prominent role. This question has not been answered before. Students of literature would need to explain why Shona liberation war fiction fails to present women as prominent guerrilla fighters. The debate on the portrayal of women in literature seems never to end and this article contributes 
significantly to that discourse. The article may even answer questions that have been asked about the roles of women in post-independence Zimbabwe. The Women in Politics Support Unit (WIPSU), for example, complains that 'Zimbabwean women fought in the liberation struggle side by side their male counterparts as equals. Today, however, their contribution to this process is not reflected at the critical decision making levels' (Anon. 2007:13). This article answers those concerns by showing that the marginalisation of women was there in the liberation war, is there in the fiction that depicts the war and continues in post-independence Zimbabwe, where, even though women constitute 52\% of the population, they are not fully represented in politics (Action Aid 2011).

\section{Influence from traditional oral literature}

What may have caused Shona war fiction writers to afford women guerrilla fighters very little space in their fiction is the effect of the patriarchal ideology that is embedded in the Shona traditional folktale. It has always been the case in Shona traditional oral literature that women are left hovering on the periphery of the plot. Although folktales were largely told by elderly women, these female narrators tended to use male characters as heroes because their own mindset was shaped by a patriarchal ideology which defined the world as male. Women rarely featured as main characters and when they did they were usually portrayed in a bad light - as victims, thieves or people who were cruel and difficult. In Shona war fiction too women are rarely, if ever, portrayed as guerrilla fighters. To do so would be to make women characters play the role of heroines, which rarely happens in Shona literature. This trend, which is also observed even in mainstream Shona novels, appears to be a carryover from Shona traditional oral literature. As Kahari (1990:216) has pointed out, 'Heroines are few and far apart in Shona literature. This is not without reason for the women have rarely been taking leading parts in the traditional folktale.'

A woman in a traditional folktale 'normally acts in a subordinate role reflecting her marginal position in society' (Ferguson 1986:8). She is usually depicted as mother, a wife, barren, a thief, cruel or a prize that men can compete to win. For instance, a king or a mother may have one very beautiful daughter whom he or she can offer as prize to anyone who will succeed to perform a very difficult task. Usually the disadvantaged of society such as lepers and other physically challenged individuals achieve such tasks. For example, in Ngano, vol. 4 (Fortune 1983) there is a story titled 'Chinyamapezi' (pp. 80-82). This is a story of a king who has a daughter who is so beautiful that he does not want her to leave home and get married to anyone. He wants her to remain within the family. The king makes a shelter on a very tall tree for her to sit in and he puts bees just below the shelter. Anyone who wants to marry this girl has to pass through the bees in order to get to the shelter. Several ablebodied men try their luck but the bees foil all their attempts.
Only the leper manages to deal with the bee stings and collect the girl from her shelter; he marries her and lives with her happily ever after. As Nandwa and Bukenya (1983:67) point out, quite a number of stories show how a man risks his life to save a woman he loves. The man who risks his life to save the woman becomes the hero of the story. In another story, also titled 'Chinyamapezi' (Fortune 1983:43), there is once again a very beautiful girl. She lives with her mother, and any man who wants to marry her has to resist the temptation to look back at her when he is leading her to his home. Several men turn to look at her when she sings. This means that they have all failed the test and they are not allowed to marry her. However, as is always the case in such stories, it is Chinyamapezi, the leper, who wins the prize. He is the only one who resists the temptation to want to look back at her when she sings and is therefore allowed to marry her. When you have a story in which a woman is given away to a man as a prize in a competition then you know that the society that tells such stories marginalises its women and treats them as second-class citizens. Rarely is a male child given away as a prize in circumstances such as those described above. Very often too girls in Shona folktales need boys to rescue them from some embarrassing predicament in which they will have put themselves because of their foolishness, thereby according the male characters hero status. As Kileff (1987) observes:

Young girls are portrayed as being vulnerable, innocent and gullible. In several stories they are deceived by smooth talking young men. In 'The men who turned into lions', it is the younger brother who saves his elder sisters from being exploited by the lion men. (p. 5)

It is this younger brother who becomes the hero and not the 'foolish' women. This stereotyping we find in Shona folktales is also carried over to novels in the mainstream where we find that female characters like Marunjeya in Karikoga Gumuremiseve (Chakaipa 1958) and Munjai in Pfumo reropa (Chakaipa 1961) are subordinate to their male counterparts, Karikoga and Tanganeropa, who will eventually rescue them and become heroes in the process. The same trend is discernible in Shona detective stories where there are no female heroes; the detective heroes are always men. The patriarchal ideology imbedded in the Shona folktales that shaped the consciousness of writers of mainstream Shona novels and those of detective fiction also shaped the consciousness of Shona war fiction writers and shaped their perspectives on women in war. It must be understood that writers of Shona war fiction belong to a generation of writers who grew up at a time when children listened to folktales told by the sarungano [storyteller] as an evening pastime and consumed overdoses of patriarchal values and culture. In addition, these same writers were indirectly influenced by the Literature Bureau which encouraged the production of literature that portrayed women as passive and unassertive. As a result 'rural women were painted as stable and morally upright. Urban women were painted as prostitutes' (Chiwome 1996:39). This kind of literature served colonial interests because the white administration wanted Africans to remain permanently in the rural areas and only come to 
town when they had their labour to offer to White business. When Black women went to town they were portrayed as prostitutes or as criminals. Only those in the rural areas were portrayed as good. So literature that was published under the supervision of the Literature Bureau rarely produced heroines. Most of the novels that depict Zimbabwe's liberation war were published under the auspices of the Literature Bureau. It is therefore not surprising that their female characters are stereotypes in a literature that is about war.

\section{Absence of women guerrillas at the war front}

One of the major reasons there are hardly any women characters who feature as fictional guerrillas in Shona war novels is that during Zimbabwe's liberation war of the 1970s women guerrillas were rarely seen at the war front, physically fighting the war alongside their male counterparts. There has never been a question or debate about the physical presence of male guerrillas in the war zones. There were millions of Zimbabwean workers and peasants who provided material and moral support to the guerrillas who never saw a single female guerrilla whilst the war was raging on, yet who saw first-hand thousands of male guerrillas who were operating in the various theatres of war around the country.

In the mid-1970s thousands of young men and women crossed into neighbouring countries hoping to train as guerrillas who would come back to Zimbabwe to fight. Many of these were young boys and girls who were abducted from schools and forced to go to war. Caute (1983:150) reports that 'during the five months from June to October 1978 it was estimated that 700 mission-school pupils crossed the border'. Many people, including those who would later become writers of the history books and the novels that depict the war of liberation, were aware that amongst the thousands of abductees and volunteers were women and girls. For instance, the abduction that was efficiently carried out by only three ZIPRA guerrillas at Manama Mission on 30 January 1977 involving from 500 people to 700 people (Bhebe 1999:172) included schoolgirls and the youngest nurses taken from the local hospital. So people knew that there were hundreds, if not thousands, of women out there making their contribution to the war effort. For this reason it was reasonable for people to expect to see armed female guerrillas as numerous as the male guerrillas that they were seeing fighting. However, most people did not see them. Those who listened to the Zimbabwe African National Union's (ZANU) radio broadcasts beamed from Maputo during the liberation war heard many female voices singing in the Zimbabwe African National Union Army (ZANLA) choir and knew that there were women and girls in the war. In addition to that the Tabex Encyclopedia Zimbabwe (Sayce 1989:279) reports that 'women fought alongside men, many of them, such as Teurai Ropa Mujuru, distinguishing themselves as military leaders'. If, as cited in Kriger (1992:191), the statistics given by Naomi Nhiwatiwa, a ZANU official, to a group in Los Angeles in July 1979 and later reiterated by Sally Mugabe in an address to a conference in Copenhagen are correct, that women comprised one-third of ZANU's guerrilla forces, it was natural that people should expect to see these female guerrillas at the front and in fairly reasonable numbers too. It must be noted that during the war everyone who crossed the border into Zambia and Mozambique under the auspices of ZANU, whether as a volunteer or as an abductee, was said to have 'gone to war'. However, it appears that there existed a gap in the minds of people between the numbers of women that they 'saw' leaving for Mozambique and Zambia and the numbers that they eventually saw, if ever they did, coming back with guns to fight. There was something missing somewhere. It is this missing link, this 'absence' of female guerrilla fighters at the war front that explains the absence of fictional characters that play the role of female guerrillas in Shona war fiction.

This article maintains the argument that if female guerrillas ever ventured deep into the interior they did so in very insignificant numbers, that it was possible that their presence could not be felt by the larger part of the population, and that this larger part of the population includes those who later became writers of Shona war fiction. Nhongo-Simbanegavi (2000:79) discovered that prior to 1978, the liberation war forces operating in the ZANLA operational zones were mostly male and for the most part the females remained in the rear base camps. This probably explains why women were not very visible at the front. The conclusion that one arrives at therefore is that this war was a men's affair because largely it was the men who were visible at the front. Images of female guerrillas holding guns were not present in the minds of the people, hence the absence of female guerrilla characters in Shona fiction.

These perceptions of the war and its principal actors were reinforced by the views of some of the writers of Shona war fiction who were interviewed. In an attempt to find out whether the images of female guerrilla fighters were ever lodged in the consciousness of writers of Shona war fiction, the writers were asked whether at any given time during the liberation war itself they ever saw a female guerrilla fighter in action. In an interview on 19 July 2007, in Harare, Aaron Chiundura Moyo said that he never met an armed female guerrilla fighter. Charles Makari, who was a headmaster and an adult mujibha [highly trained war collaborator] in the Zaka/Nyajena area in the 1970s and who later published a novel about the war, said:

No. I only heard about female carriers who ferried weapons to the front but I did not even see them. That is why female guerrillas do not feature in my novel, Zvaida Kushinga. (Interview with Charles Makari. Harare. 20 July 2007)

Asked when it was that he first saw an armed Black woman in military fatigue Mr. Makari said it was at the army barracks where he had gone to see a relative soon after independence. Vitalis Nyawaranda, who was teaching in the Tanda rural area during the liberation war, also said in an interview on 20 July 2007, in Harare, that he never saw a woman guerrilla during the war, and did not see one even when he went to an assembly point during the ceasefire. 
It is possible that if writers had been amongst those who had the experience of seeing female guerrillas in action during the liberation war they would have featured them in their novels. It probably would have been an exceptionally exhilarating experience to see these 'ladies of the war', as Bonde (1990:4) shows, 'Women guerrillas? With real guns, machine-guns, ammunition gondoliers, rucksacks, grenades...? Women soldiers dressed like men - complete with denims and boots? They were a sensational phenomenon in those days.'

Such a phenomenon was good material for use in writing a work of art. Unfortunately, this phenomenon was not commonly seen. Just as much as there was 'absence' of female guerrillas at the war front, so too there is an absence of female guerrilla characters in Shona war literature.

The point being made here is not that there were no trained female guerrillas. The point is that they were not seen by many in the main theatres of war. This seems to confirm what Nhongo-Simbanegavi (2000:82) discovered in her research that, 'The percentage of women was always low. Whenever there was danger of enemy attack ZANLA would always withdraw their women fighters to the rear.'

What this shows is that women were usually removed from where real action was taking place. Where real action was taking place is where observers focused attention and that is where all who mattered as far as tough action was concerned could be seen. However, as Nhongo-Simbanegavi (2000) asserts:

There is no evidence suggesting that those areas ZANLA categorized as 'contested' ever saw a single woman guerrilla. ... Consequently, the handful of women deployed to the front were more likely to be found in ZANLA's rear detachments, the areas bordering Mozambique and nearest to ZANLA's rear bases. (p. 83)

That probably explains the absence of women guerrillas from areas deep in the interior where most of the action was taking place. Perhaps critics should also take a serious view of what Joyce Teurai Ropa Mujuru, a female ex-combatant and the first woman cabinet minister, said in an interview with Moto (Bonde 1990). In a somewhat evasive answer to the question 'Did women comprise a significant part of the guerrilla force?' her response was:

To us fighting was not only the triggering of a gun, but one's contribution, whether as a teacher (of refugee children), or as an instructor, or as a commissar giving political education to recruits. (p. 4)

She also added in response to another question that 'we also had women who were assigned other duties other than going to the front', and that 'we never considered one's sex, but just assigned duties according to one's capabilities'. Perhaps it was after considering women's capabilities that, from early 1970s ZANLA deliberately recruited women, but not for combat duties. ZANLA leaders allocated women roles as cooks, nurses and, above all, as porters and carriers (NhongoSimbanegavi 2000:xix).

Martin and Johnson (1981:82) seem to agree with NhongoSimbanegavi on this issue. They discovered in an interview that Susan Rutanhire, who crossed the border with her husband George, spent two years at Chifombo carrying armaments to the front, and that they used to be escorted by ZANLA guerrillas. Obviously during these two years, her husband George was at the front, fighting. So people probably saw George fighting at the front, but did not see Susan. Even after her training at Frelimo's Nachingwea camp in Tanzania she became a weapons instructor at Chimbichimbi Camp in Zambia. So Mujuru's statements, that to them fighting was not only a matter of triggering the gun and that duties were assigned according to capabilities, are quite insightful. Women were not seen at the war front because they were performing other duties that they were capable of doing at the rear. Miranda Davies (cited in Kriger 1992:191) could therefore be correct in her observation that the number of women combatants was small, and that females who left Zimbabwe hoping to join the guerrillas were usually asked to look after children. Davies's observation tends to give weight to the argument raised by Bhebe and Ranger (cited in Lyons 2004:29) that there have been too many attempts to produce a heroic 'herstory' of the war, attempts which have overestimated the number of female guerrillas in the liberation war.

If one puts together the thoughts expressed in Mujuru's responses to Moto, one tends to appreciate Lyons's (2004:29) concern that 'there has been a sustained and growing ambiguity as to what it was that women actually did in the liberation war'. However, what is clear is that women who joined up in the early 1970s were at first mainly used to carry supplies and weapons, but as air raids and other attacks by Rhodesians increased women demanded to be trained in order to protect themselves (Nhongo-Simbanegavi 2000; Lyons 2004).

This image of absence of female guerrillas was reinforced by the fact that ZANU's component of the Patriotic Front attending the London conference was entirely male and the ZANLA leaders who came into Zimbabwe to liaise with the Commonwealth Monitoring Troops to get the fighters into the assembly points were also all male, except for one woman whom press identified as Linda Tafadzwa (Nhongo-Simbanegavi 2000:127). On the other hand many young women came back from Mozambique carrying babies on their backs, suggesting that instead of fighting they were probably being used as what Chung (2006:126) calls 'warm blankets' who performed 'night duties' at the rear. The conclusion that one can therefore draw is that because 'ZANLA deployed few women fighters inside Zimbabwe' (Nhongo-Simbanegavi 2000:127) and its ZIPRA counterpart did not even deploy its female cadres to the front (Bonde 1990:5), those who would become writers did not see them. Hence, images of women guerrilla fighters are also absent in Shona war fiction.

\section{Pioneer soldiers and the naming of reality}

The other major factor that shaped writers' perspectives on the liberation war in Zimbabwe is the language that was 
adopted specifically to depict the war. The language that was used throughout the war period and after independence was man-made. The term 'man' here is not used to mean the human race; it is used to mean the male gender as opposed to the female gender. It appears that during the liberation war men had a complete monopoly over the language that was used to point to things, objects and people. This monopoly ensured the primacy of the male and reinforced female invisibility. The net effect of this is that the discourse about Zimbabwe's liberation war became a discourse of the male gender. Women were excluded from that discourse.

The reason for the exclusion of women from war discourse is that men were the pioneer soldiers of Zimbabwe's liberation war. For example, early groups of fighters were made up of young men and no women. ZANU's first group of five guerrillas that went to China for training on 22 September 1963 was made up of Emmerson M'nangagwa (leader), John Shonhiwa, Eddison Shirihuru, Jameson Mudavanhu and Lawrence Swoswe, all men (Martin \& Johnson 1981:11). The second group included William Ndangana, Bernard Mutuma, Silas Mushonga and Felix Santana (Martin \& Johnson 1981:11), again all men. The famous seven guerrillas who perished in a fierce encounter with Rhodesian troops at the Battle of Sinoia in 1966 were likewise all men Simon Chimbodza, Christopher Chatambudza, Nathan Charumuka, Godwin Manyerere, Arthur Maramba, Ephraim Shenjere and David Guzuzu (Sibanda \& Moyana 2002:82). The first four ZANLA guerrillas sent to join FRELIMO in Tete in mid-July 1970 and led by Mayor Urimbo were all men (Martin \& Johnson 1981:21) and so was the unit of 21 men in the Nehanda sector of the Mozambique-Zimbabwe border which was commanded by Rex Nhongo and which fired the first shots of the decisive phase of the war in December 1972 (Martin \& Johnson 1981:73).

These groups have been selected to illustrate that during the early phases of Zimbabwe's armed struggle war was a men's affair. There were no women who rose to prominence during that time. According to Martin and Johnson (1981:21) the four men - Mayor Urimbo (leader), Justin Chauke, Cornelius Mpofu, and Shumba - 'and thousands who came after them, came to be known affectionately in the kraals and villages of Zimbabwe by the Shona word vakomana, literally "the boys"'. Frederikse (1982:xii) defines the word vakomana as a 'Shona word meaning boys, used affectionately by black Zimbabweans to refer to the guerrillas or "the boys in the bush"'. It is not quite clear how the word came to be used and who started it but it is possible to speculate that the word vakomana [boys] gained currency because the war came to the people with 'the boys' or simply young men, such as 'the boys' who comprise the groups given above. The word vakomana was used interchangeably with the word vanamukoma, literally 'brothers'. When the war started there were no women guerrillas, so no gender sensitive terms were used to depict things and people; even after women entered the war they remained largely invisible at the front where these words were adopted and their assumed new meanings popularised.
The terms given above were adopted by the people for use in addressing their freedom fighters with respect and affection. However, there was another term that was adopted by the Rhodesian regime to refer to guerrillas with disdain and hatred. The Rhodesian regime regarded the nationalist guerrillas as terrorists who committed senseless murders and hence they called them magandanga [terrorists] (or gandanga when referring to one). Frederikse (1982) defines the word magandanga as a Shona word that describes a thug or criminal. However, the Shona people themselves use gandanga [murderer] to describe someone who waylays people and murders them. According to the Shona dictionary, Duramazwi Guru ReChiShona (Chimhundu 2001), gandanga means, amongst other things, 'munhu mhondi kana akapanduka' [a murderer or a person who became wild] or 'munhu anohwandira vanhu achivauraya' [a person who waylays people and kills them]. The latter definition is closer to the definition of gandanga given by Staunton (1990:xiii) who defines it as 'a wild savage person, an ogre'; an ogre is also defined by Chesaina (1991:24) as 'a symbol of evil and power of destruction which lurks in the world'. Murder is a criminal offense far worse than other illegal activities such as stealing or assault; a gandanga to the Shona is a murderer.

The Shona people themselves never used the term magandanga [murderers] to refer to their freedom fighters. Although the guerrillas' business was to kill because they were fighting a war, the people never saw them as murderers. That term was used by Rhodesians. The guerrillas also used the terms ma/gandanga to refer to themselves in conversations with the people, but only when they wanted to be sarcastic. The people were careful to let the guerrillas call themselves what they wanted but they would never use offensive terms like ma/gandanga to refer to their freedom fighters.

The word ma/gandanga refers to guerrillas because the pioneers of the war were males. In the Shona mindset women are never regarded as magandanga. Women do not waylay people and murder them; in the Shona culture, women are more associated with witchcraft: if they want to kill they are more likely to use witchcraft, which does not require violence. However, a woman could be described as gandanga remukadzi [a murderer-like woman] if she displayed the attributes of a murderer. This implies that whilst gandanga is a male, a woman who behaves like one could be described as such as well. That is why Nhongo-Simbanegavi (2000:46) says that war has always been conceptualised as a male activity and women who take part in it must be as like men as possible.

The terms described above were all used to refer to males. Makari (1985:12) has all of them in just one paragraph in his novel Zvaida Kushinga: 'Isu tinonzi makomuredzi. Vamwe vanotidaidza kuti vakomana kana kuti vanamukoma. Tiri varwiri vorusununguko. Vavengi vanotiti magandanga'. [We are called comrades. Others call us boys or the brothers. We are freedom fighters. Our enemies call us murderers.]

The use of these terms - vakomana, vanamukoma, magandanga - during the liberation war denied female guerrillas space in 
war discourse and eventually in Shona literary discourse as well. In fact these terms later came to encompass everyone, male or female, who later joined the war that was started by the male pioneers. The use of such terms during the actual war itself gave some Shona war fiction writers the perspective that war was a men's affair. This was not without some justification. When one of the people to come into contact with the first ZANLA guerrillas in the northeast of Zimbabwe, George Rutanhire, was recruited, he was told to bring his wife as well but he 'was not sure about a woman's place in war' (Martin \& Johnson 1981:81). On the other side 'it was part of the Rhodesian macho mores that war was the responsibility of men, so they were completely unprepared to fight against women' (Chung 2006:81). So whilst it is plausible to point out that male terms were used to name things during the liberation war because men were the pioneer soldiers we should not lose sight of the fact that society was also conservative, having been schooled in strong patriarchal traditions. If society's ideological outlook had been different then, perhaps, terms denoting females would have been adopted later when women came on board. No female terms were ever used to name guerrillas.

Whilst during the war terms like vakomana, vanamukoma and magandanga were used to name reality, there were no terms like vasikana [girls], vanasisi [sisters], vanatete [aunts] or the like that were used to at least recognise the presence of the few female guerrillas in the war. Although the more neutral term khomuredhi [comrade] was used to address anyone, be it male, female, guerrilla, worker, peasant, mujibha, chimbwido [war collaborator] or even an enemy, it was nevertheless a word that made people think male. Whenever the word khomuredhi was mentioned people first thought of guerrilla boys rather than of guerrilla girls. Nyawaranda (in an interview on 20 July 2007) insisted that khomuredhi was synonymous with male. The conclusion one draws is that the use of terms like vakomana, vanamukoma, magandanga and even makhomuredzi [comrades] resulted in the formation of the image of man in the mind. This can be likened to the way people use man (and he). As Spender (1980) points out:

man (and he) is in constant use as a term which supposedly includes females, and one of the outcomes of this practice has been to plant man uppermost in our minds. (p. 151)

So too the effect of the constant use of vakomana, vanamukoma, magandanga and makhomuredzi during Zimbabwe's liberation war was to plant man uppermost in the minds of people, including the minds of future writers of Shona war fiction. These are the terms used to name the guerrillas in Shona literature about Zimbabwe's liberation war which ensures, as Spender (1980:157) puts it, that 'in the thought and reality of our society it is the males who become the foreground while the females become the blurred and often indecipherable background'.

When asked why Shona war fiction writers use masculine terms without also using terms that denote female guerrillas, Aaron Chiundura Moyo, who wrote some Shona war stories, said:
Men were first to appear as fighters. These are terms that were used for them. Women were few. Leaders were men. These terms that we used in our stories were used in the war, so we got them from there. (Interview with Chiundura Moyo. Harare. 19 July 2007)

When Charles Makari (1985) was asked in an interview on 20 July 2007 why he does not use gender sensitive terms in his war novel Zvaida Kushinga he also reiterated what Mr Moyo said that 'Many early fighters were men. Men lead in war. The first fighters who impressed people were men'.

The use of the words vakomana, vanamukoma, and magandanga makes males linguistically visible and females linguistically invisible in Shona war literature. As one reads Shona stories about the liberation war one becomes conscious of the male imagery at the expense of the female imagery. Even if we were to put aside the issue of these terms we would still find that rules of conduct with regard to sexual offences during the war are given in language that is man-made. The rules are meant to prevent men from committing sexual offences. There is no evidence to suggest that it is women's behaviour that is being sanctioned. For example, in Sungano's (1985:88) Kuda Muhondo the battalion commander who gives the rules of conduct to trained guerrillas that are about to leave for the front says: 'Chetatu, upombwe. Musambozofe henyu makaita upombwe muhondo umu. Munhu akaita dumbu muhondo vabereki vake voziva kuti ndimi havangambokufarirai. Munotengeswa mukapera kufa.' [The third thing is sex. Do not ever indulge in sex in this war. If someone becomes pregnant and her parents know that you are responsible they will not like you. They will sell you out and you will perish.]

Such an instruction cannot be directed at women. The language in the warning is meant for a male audience, and women would be the victims in the equation. In Nyawaranda's (1985) Mutunhu Une Mago the spirit medium, again in language that is man-made and meant for men, warns the guerrillas who consult him: 'Imi kana muri vavhimi chaivo, regai kubata-bata vemadhirezi ava' [If you are genuine hunters do not touch women] (p. 112). Again this is an instruction given to male fighters. In the metaphor used men are the hunters who should not womanise if they are to succeed. Women are just objects and touching them becomes taboo. There are no rules given that suggest that the writer or the spirit medium sees women in this war who also need to be protected against '(wo)manising'. War is men's business and rules are made in language that is meant for men's survival.

Perhaps this thinking can be understood better against the background that in traditional society men were expected not to sleep with their women on the eve of a hunting expedition. The general belief was that if they did they would not succeed in catching animals, as the animals would evade them. Whether it is in hunting or in Zimbabwe's liberation war, it is the women who should be marginalised so that for the time being men can get on with the serious business at hand in which women are not central. So writers held this perspective on the war, the perspective that Zimbabwe's liberation war was men's business, and they did so in response to the way 
naming of reality occurred during the actual war that they were depicting. As Spender (1980) points out:

In order to live in the world, we must name it. Names are essential for the construction of reality for without a name it is difficult to accept the existence of an object, event, a feeling. (p. 163)

Female guerrillas were not 'named' in the actual liberation war itself, hence writers too did not accept their existence, and that explains the paucity or even the absence of guerrilla girls in Shona war fiction. The problem is, however, compounded by the fact that Shona war fiction was written by men, which takes us to the next point of our discussion.

\section{Absence of women writers of Shona war fiction}

One of the possible reasons why women guerrilla fighters are linguistically invisible in Shona war fiction is that most, if not all, stories were written by men and from a patriarchal perspective. Chigidi (1998) studied Shona detective fiction and discovered that male authors wrote all Shona novels that deal with crime and detection. As a result there are no female detective heroes in the fiction. Women are depicted as stereotypes. Similarly, all Shona novels that deal with Zimbabwe's war of liberation were written by men. As a result women are once again depicted stereotypically. One tends to agree with Spender (1980:191) who says that many people would be quick to challenge the assertion that women constitute a muted group in terms of the written word. However, it cannot be denied that Zimbabwean women have not written novels that tell the full story of their active participation in the war. The story of the liberation war in Zimbabwe is a tale told by men who choose male characters and cast them as guerrillas and heroes. Lyons (2004:19) has challenged Zimbabwean women by quoting an African proverb: 'Until lions have their own historians, tales of hunting will always glorify the hunter'. This concern is also forcefully expressed by Murray (1973):

Since her appearance in Genesis, woman has been a prisoner of the imagination of others, is seen trailing clouds of glory or dust or whatever has been flung at her, always as the object, not as the creator of her own self, fully fleshed out in the primary imagination. (p. 19)

Lyons's and Murray's concerns are justified in this case by the fact that seven major Shona war fiction writers Makata, Makari, Pesanai, Nyawaranda, Sungano, Choto and Musengezi - all males, fail to create a single female guerrilla fighter character. They do not even attempt to make chimbwidos their heroines. All their heroes are men. Perhaps these male writers ignored the role women guerrillas played in the liberation war because as Pfukwa (2003) observes:

There is insufficient data on the role of women in the guerrilla war. Most of the records were made by men from their own perspective and tended to overlook the role of women. (p. 21)

This thinking tends to agree with the concern held by Lyons (2004) about what exactly women did in the liberation war. Male writers tend to depict women as stereotypes because they did not think women had a place in war. When asked why Shona war fiction writers did not depict women as guerrillas in their novels, Nyawaranda, one of the Shona war story writers, had this to say in an interview:

Generally only men go to war. We were influenced by sex-role stereotypes that said war is for men. The idea that women go to war came with the struggle for independence. Rhodesia African Rifles were men. During World War 11 only men went to war. Ndebele impis had no women. I went to an assembly point and I did not see one, and so old perceptions about women's role in war were reinforced in me. (Interview with Vitalis Nyawaranda. Harare. 20 July 2007)

There are several examples that can be cited to illustrate that liberation war fiction was written from a men's perspective that does not seea woman's place in war. In Morgan Mahanya's (1984) short story Hapana Chinodyiwa Chisina Muzorera there are two characters, a brother and a sister, Gladys and Gibson, who are both involved with the war in one way or another. However, of the two siblings, it is Gibson, the male, who absconds from Chibi Mission to Mozambique to train as a guerrilla fighter whilst the sister, Gladys, remains behind to train as a nurse. As fate would have it, Gibson comes to operate in areas around Kwekwe where Gladys is working as a nurse in a hospital. It is therefore Gladys the woman who provides for Gibson's needs whilst Gibson the man fights the war. This story is structured in such a way that Gibson, the male character, is permitted primacy and dominance whilst the woman, Gladys, plays a secondary role. Mahanya is one of the pioneers and prominent writers of Shona detective stories in which men are detective heroes whilst women are just victims, mothers, wives and, worse still, criminals. It is therefore not surprising that in this war story genre Mahanya once again makes female characters occupy a restricted space in the 'home' whilst the male is allowed to go out into the 'world'.

Another example that shows that men will have none of what Ngcobo (1988:150) calls the independence of the female spirit' comes from Nyawaranda's (1987:12) Paida Mwoyo. When Nyawaranda creates Chipo's character the readers get the feeling that at last they are going to see a woman who will undertake a journey of adventure with all its risks and perils. This feeling is reinforced by Chipo's own bold and suicidal statement that: 'Kana ndichinge ndadzingwa chikoro chacho, ndotokirosa zvangu kuMoza. ... Nyangwe ndife zvangu ndichirwa nemasoja aSmith, ndiko kuti ndizorore zvangu. Ko, kusiri kufa ndokupi?' [If I am expelled from school, I will go to Mozambique ... If I die fighting Smith's soldiers that will be one way of getting rest. What other option is there besides dying?]

The expectation of seeing a woman who will eventually become the first female fictional guerrilla in Shona literature is further strengthened when, in the middle of the night, Chipo is seen bidding Tapera, her teacher and benefactor, farewell. There are people waiting somewhere outside the school to assist her and others cross the border into Mozambique and before sunrise she would be gone. However, the independence of the female spirit about to be displayed will not be allowed to prevail in a society that upholds patriarchal values. Probably because of his perception that only men go 
to war (obtained in interview), Nyawaranda abandons the plot of a woman's adventure story. Instead he follows a plot that takes us on 'a non-believer's journey'. Chipo ceases to be the protagonist of the sub-plot. The protagonists of the new sub-plot are an unnamed guerrilla and Tapera, who are both men. Chipo and Tapera are arrested, and in a brief James Bond type of operation carried out in an attempt to rescue them Chipo is shot and killed, her dreams of becoming a guerrilla girl ended. The two men survive but the plot loses the war interest that it picked up earlier on. The woman character is dead. Tapera pursues his educational goals. The male guerrilla, who has been introduced just to display his heroic antics, is not heard of again. Possibly he has gone to join the rest of the vakomana [boys] whilst the representative of the vasikana [girls] goes under. This is the price that women pay for having others speak for them and on their behalf. There are no women writers to tell their own war stories.

Shona war fiction is dominated by patriarchal values and a patriarchal culture and that explains why there are no female guerrillas. This is seen in the way male authors belittle female characters. One good example of how women characters are treated with disdain by male authors is the way Tsitsi, a prominent chimbwido in Choto's (1990) Vavariro, is portrayed. Perhaps in an obvious effort to show that women have no place in battle, when planes come and throw bombs Tsitsi is portrayed as a spoiler who throws spanners in the works, whilst Tumirai is the guerrilla hero who repulses the attackers. The man wants to fight back the Rhodesian planes but the woman wants them to run away without even considering safety first. Worse still, Tsitsi holds Tumirai's arms in such a way that the hero cannot shoot at the enemy planes. Tsitsi, the female character, is now a danger to the revolution. The desperation in the guerrilla's voice shows that Tsitsi is now a real nuisance. Tumirai pleads, whilst pushing the woman away: 'Usandibate kani Tsitsi. Rega ndidonhedze ndege iyi.' [Do not hold me Tsitsi please. Let me bring down this plane.] (p. 63). He adds: 'Ndinopfura sei kana wakandibata maoko? Ibva mhani Tsitsi!' [How can I shoot while you are holding me? Get away Tsitsi!] (p. 63).

Even under these circumstances Tumirai is able to down one plane but misses the other one because a woman is unsettling him. The author gives the man more power than the woman. The whole episode has the effect of making Tsitsi look silly, overwhelmed by a situation she cannot handle. Against her timidity and weakness the man's stature is thrown into sharper and bolder relief. Choto shows clearly his contempt for women in war. He seems to be interrogating the prudence of involving women in wars, for he seems to be insinuating that war is not a place for women. Choto later shows where he thinks women belong when he makes Tsitsi express her longing for a settled life of marriage, love, wifehood and motherhood. This is the role that a woman character is made to play, that of a spoiler and not that of hero. In fact her role is anti-heroic.

One advantage of Choto's anti-heroic vision is that it allows for one moment of glory. Tsitsi does not succumb to patriarchal pressure completely. She rises up from her humiliation with some degree of admiration to plant a bomb in a Whites-only hotel in Harare that kills 50 White people when it explodes. She receives a full round of applause from fellow comrades back in the bush but had she been a male guerrilla fighter she would have been accorded a place in the annals of history such as the one accorded to those male guerrillas who carried out the 'daring attack on the fuel storage depot in Salisbury in December 1978' (Chung 2006:238). Instead, no sooner than Tsitsi achieves her feat than she is reduced once again to her small place in the home where the male author, so it seems, believes she belongs. In the middle of war, with guns and bombs exploding, Tsitsi talks seriously of wanting to go home because she wants to get married. She makes no secret of the fact that she is tired of the war and wants to go home and take a good rest. Only women are made to be so naive as to imagine that after flirting with guerrillas they can go home and rest in marital bliss and the Rhodesian soldiers will leave them in peace. Instead of concentrating on the war that the boys are concentrating on, she is reduced to thinking about marriage and motherhood in a manner that makes it seem as if that is all that matters to women. It reminds us of Murray's (1973:16) comment that a woman's world 'has been a world of birth and death, of food and love, of comfort and blood - a very basic world'.

Choto's portrayal of Tsitsi can better be understood if it is viewed alongside the portrayal of yet another female character, Angela, in Charles Samupindi's (1992) English novel, Pawns. Like Tsitsi, Angela is not a guerrilla woman. She is a mere chimbwido. Her role is to admire and appreciate the plight of the men who are fighting the war. She says:

What is the cooking, and doing the dishes compared with the battle front? After these pungwes we go back to our comfortable huts and leave you to contend with the harsh night and the dark land. (p. 134)

At least Angela eventually leaves for Mozambique and is successfully trained as a guerrilla fighter. Perhaps the reader feels that Samupindi has succeeded to do what Shona war fiction writers like Nyawaranda $(1985,1987)$ have failed to do, that is to allow a female character to train as a guerrilla fighter and send her to the front to actually fight. However, the reader is soon disappointed to realise that Pawns (Samupindi 1992), like Vavariro (Choto 1990), is dominated by patriarchal culture and values. The patriarchal resentment of the independence of the woman's spirit is manifested when, again in the middle of exploding guns and bombs, Angela sincerely hopes the war will come to an end so that she can go and lead a normal life. Her definition of a 'normal life' is expressed in two statements that she makes at Mavonde in a conversation with Fangs, the male guerrilla commander:

I don't know, every woman dreams that one day she will have her own home, raise her own children and family, participate in something which grows, something creative. (Samupindi 1992:174)

But now all I want is to have a family, with you [Fangs].... I want to think about the future in a way I can understand with a home and a family. (Samupindi 1992:175). 
If both Tsitsi in Vavariro (Choto 1990) and Angela in Pawns (Samupindi 1992) are allowed to have their way it would have the effect of removing them physically from where all the action is, thereby reinforcing the image of absence and the invisibility of female characters and the image of the primacy and dominance of the male characters. Uko (2004) has rightly pointed out:

At adulthood and in marriage, the woman is assumed to have been properly grounded in servitude, muteness, invisibility and dependence, with a natural acceptance of a corresponding male superiority and dominance. (p. 130)

Samupindi's (1992) woman guerrilla and Choto's (1990) chimbwido who, in the middle of a terrible war, are dreaming of a settled life with a man whilst the men are thinking of strategies to prosecute the war, confirm Ferguson's (1986) point:

In every age woman has been seen primarily in her biological, primordial role as the mysterious source of life. Women have been viewed as mother, wife, mistress, sex-object-their roles in relation to men ... Cave drawings that show men casting spears or running after a boar also show women pregnant, their secondary sexual characteristics grossly exaggerated so that they seem all bosom, belly, and butt. Man has been defined by his relationship to the outside world-to nature, to society, to Godwhereas woman has been defined in relationship to man. The word defined means 'being a limit around', 'fenced in'. Women have been fenced into a small place in the world. (pp. 4-5)

Hence, Tsitsi and Angela dream of life with a man as their priority. Samupindi, like Choto and Nyawaranda, is a patriarch who sees no role for women in war. When Mavonde is attacked by the Rhodesian Air Force and Infantry, Angela, the trained guerrilla girl, is there. So too is Fangs, the guerrilla commander. Yet Samupindi (1992) tells us that 'on the ground, it was men against men' (p. 77), not women against (wo)men. It is Fangs the guerrilla boy who fights to the bitter end and not 'Angela of unbridled passion. Angela of bright, loving eyes. Angela!' (p. 80) (Fangs once made love to Angela when she was a chimbwido at the front). Angela is not described anywhere fighting in the battle. She is only seen as a sex object in Fang's imagination. It is only after the battle is over that Fangs, the guerrilla hero, searches for Angela, of unbridled passion, not of heroic action, and finds 'her body dangling from a tree, a metre from the ground' ( $p$. 182), dead. The reader does not hear a single shot fired by her, and another opportunity to show a female guerrilla in action is lost. Even Mazorodze (1989) in Silent Journey from the East merely refers to a woman guerrilla, Comrade Shungu Dzehondo, as the commander in charge of 300 men. The woman is remembered by Alexio (p. 77) but she is never seen firing a shot.

The depiction of Angela in Pawns (Samupindi 1992) has been used alongside the depiction of Tsitsi in Vavariro (Choto 1990) to reinforce Lyons's (2004:27) point that 'a discussion of women as fighters is mostly absent from the discourse about war by both male and female writers'. The view of women's role in war vis-à-vis their perceived natural roles in the domestic sphere has dominated the perceptions, assumptions, and stereotypes of women in war
(Lyons 2004:19). Until women writers emerge to tell their own story about their own involvement in the liberation war guerrilla girls will remain absent from the discourse about the liberation war in Shona literature.

\section{Conclusion}

The major argument that has been advanced in this article is that other than as chimbwidos (female war collaborators) women do not seem to have a meaningful role to play in Shona war fiction. Women guerrilla fighters are conspicuous by their absence in fiction that is about a guerrilla war. They are absent because women rarely feature as heroines in Shona literature. Also most people, including those who later gave accounts of the war as writers of war fiction never saw a single female guerrilla throughout Zimbabwe's liberation war. Another argument that has been raised is that the pioneers of the guerrilla war were almost all men and hence in their consciousness people came to associate the liberation war with men. By the time women were recruited to join the war the language that was essential for the construction of reality was already in place and it marginalised women. This is the language that writers adopted in their works. The final point raised is that the negative portrayal of female roles in the liberation war results from a lack of women writers who can tell the story of the war from the women's perspective. The point that the chapter raises is therefore that as long as women do not tell their own story and portray positive images of women's involvement in that war men will continue to give glorified accounts that revolve around men whilst painting pictures of pitiful girls who long to get married and produce children for male guerrilla fighters. If, as it is always claimed, women fought side by side with their male counterparts, then realism would demand that at least some war novels feature women as main characters and heroines. Presenting women as heroines in war does not necessarily mean portraying them as armed soldiers who kill and maim. It also means portraying women in war who perform heroic deeds as mothers who give, protect and sustain life, as nurses who treat and save the wounded and the dying and as chimbwidos who avert disasters. Writers should portray women as heroines and as main characters in these capacities and if male writers cannot do that because of their ideological outlook then women writers should.

\section{Acknowledgements Competing interests}

The authors declare that they have no financial or personal relationship(s) which may have inappropriately influenced them in writing this article.

\section{Author contributions}

W.C. (Midlands State University), then a student of The University of South Africa, wrote the manuscript. D.E. (University of South Africa), then a promoter, contributed material related to the war of liberation and guided the writing. 


\section{References}

ActionAid, 2011, Zimbabwe women demand for food security as they celebrate International Women's Day, viewed 20 February 2013, from http://www. actionaid.org/zimbabwe/news/zimbabwe-women-demand-food-security-theycelebrate-international-women\%E2\%80\%99s-day

Anon., 2007, 'Feature', The Financial Gazette 13, 05-11 July.

Bhebe, N., 1999, The ZAPU and ZANU guerrilla warfare and the Evangelical Church in Zimbabwe, Mambo Press, Gweru.

Bonde, D., 1990, 'A luta continua', Moto 24, November, 4-6.

Caute, D., 1983, Under the skin: The death of Rhodesia, Allen Lane, London.

Chakaipa, P., 1958, Karikoga Gumiremiseve, Longman, Salisbury.

Chakaipa, P., 1961, Pfumo reropa, Longman, Salisbury.

Chesaina, C., 1991, Oral literature of the Kalenjin, Heinemann, Nairobi.

Chigidi, W.L., 1998, 'The emergence of the Shona detective story as a fictional genre in Zimbabwean literature', MA dissertation, Department of African Languages, University of South Africa, Pretoria.

Chimhundu, H., 2001, Duramazwi guru reChiShona, College Press, Harare.

Chiwome, E.M., 1996, A social history of the Shona novel, Juta Zimbabwe, Eiffel Flats. Choto, R., 1990, Vavariro, Baobab Books, Harare.

Chung, F., 2006, Re-living the Second Chimurenga: Memories from Zimbabwe's liberation struggle, The Nodic African Institute, Stockholm.

Ferguson, M.A., 1986, Images of women in literature, 4th edn., Houghton Muffin Company, Boston. PMid: 6556452

Fortune, G. (ed.), 1983, Ngano, vol. 4, Mercury Press, Harare.

Frederikse, J., 1982, None but ourselves: Masses vs media in the making of Zimbabwe, Zimbabwe Publishing House, Harare.

Kahari, G.P., 1990, The rise of the Shona novel, Mambo Press, Gweru.

Kileff, C. (ed.), 1987, Shona folktales, Mambo Press, Gweru.

Kriger, N., 1992, Zimbabwe's guerrilla war: Peasant voices, Baobab Books, Harare.
Lyons, T., 2004, Guns and guerrilla girls: Women in Zimbabwean national liberation struggle, Africa World Press, Asmara.

Mahanya, M., 1984, 'Hapana chinodyiwa chisina muzorera', in Literature Bureau (ed.), Hondo yeChimurenga, pp. 114-125, Mambo Press, Gweru.

Makari, C., 1985, Zvaida kushinga, Mambo Press, Gweru. PMid:3904469

Martin, D. \& Johnson, P., 1981, The struggle for Zimbabwe, Zimbabwe Publishing House, Harare.

Mazorodze, V.I., 1989, Silent journey from the east, Zimbabwe Publishing House, Harare.

Murray, M., 1973, A house of good proportion: Images of women in literature, Simon and Schuster, New York.

Nandwa, J. \& Bukenya, A., 1983, African oral literature for schools, Longman Kenya, Nairobi.

Ngcobo, L., 1988, 'African motherhood-myth and reality', in K.H. Petersen (ed.), Criticism and Ideology, pp. 141-154, Scandinavia Institute of African Studies, Uppsala.

Nhongo-Simbanegavi, J., 2000, For better or worse: Women and ZANLA in Zimbabwe's liberation struggle, Weaver press, Harare.

Nyawaranda, V., 1985, Mutunhu Une Mago, Longman Zimbabwe, Harare.

Nyawaranda, V., 1987, Paida mwoyo, College Press, Harare.

Pfukwa, C., 2003, 'Onomastic innovation in Zimbabwe noms de guerre', Language Matters: Studies in the Languages of Africa 34, 13-23.

Samupindi, C., 1992, Pawns, Baobab Books, Harare.

Sayce, C., 1989, Tabex Encyclopedia, 2nd edn., Quest Publishing, Harare.

Sibanda, M.J. \& Moyana, H., 2002, The African heritage Book 3, rev. edn., Zimbabwe Publishing House, Harare.

Spender, D., 1980, Man made language, 2nd edn., Pandora Press, London. PMCid:1600110

Staunton, I., 1990, Mothers of the revolution, Baobab Books, Harare. PMCid:1292467 Sungano, J., 1985, Kuda muhondo, Mambo Press, Gweru.

Uko, I., 2004, 'A failed sexual rebellion: The case of Ama Ata Aidoo's Anowa', in E.N. Emenyonu, New women's writing in African literature 24, pp. 130-137, James Currey, Oxford. 